\title{
The Effect of Multiple Rebranding on Customer Loyalty in Nigerian Mobile Telephony
}

\author{
Alexander C. Tevi ${ }^{1}$ \\ ${ }^{1}$ School of Media and Communication, Pan African University, Lagos, Nigeria \\ Correspondence: Alexander C. Tevi, School of Media and Communication, Pan African University, Lagos, \\ Nigeria. E-mail: alextevi@yahoo.com
}

Received: December 13, 2012 Accepted: January 23, 2013 Online Published: March 5, 2013

doi:10.5539/ijms.v5n2p120 URL: http://dx.doi.org/10.5539/ijms.v5n2p120

\begin{abstract}
Econet Wireless, a Nigerian mobile telephone network rebranded five times within the space of eight years to become what it is today, Airtel Nigeria. This research sought to know the impact of multiple rebranding on the loyalty of the network's subscribers and the general attitude of the Nigerian towards branding in the telephony business. A survey was carried out on subscriber attitude towards Airtel as a result of the multiple rebranding through which it emerged. Questionnaires were distributed based on cluster sampling. Pearson Chi-Square was used to test the validity of the final results (cross tabulations) on a value of 0.05 and above. This research confirms communication as the vehicle for transferring brand equity; shows that multiple rebranding does not significantly affect attitude towards telecommunications brands; and that Nigerians do not really care about branding in telecommunications and/or the telecommunications companies are not doing a good job of branding. This study focuses on only a segment of the global satellite mobile (gsm) market - students of a higher institution. The perspective of the students may not be representative of the whole global satellite mobile (gsm) market in Lagos. It is also limited to the telephony market in Nigeria, an emerging market. This is an original work in the sense that there is no literature anywhere on the phenomenon of multiple rebranding, let alone its effect on customer loyalty.
\end{abstract}

Keywords: global satellite mobile (gsm), branding, rebranding, multiple rebranding, brand equity, customer loyalty

\section{Introduction}

The economic climate of the developed world has been experiencing a stormy weather in recent years. This quickly spreads on the wings of globalization to the developing world. One of the industries that have been impacted the most is telecommunications. The changes that have taken place in Econet Wireless, the first mobile telephone company to start operations in Nigeria, epitomises this impact. It started business in 2001, became Vodacom for only three months; became V-mobile immediately after that; became Celtel in 2006; became Zain in 2008; and finally became Airtel in 2009. The network that is today called Airtel in Nigeria has undergone five revolutionary rebranding (Muzellec\& Lambkin 2006) exercises within eight years of operation. The whole essence of branding is to build brand equity (Aaker 1996). Renaming, a revolutionary rebranding, destroys the equity of the previous brand. By extension, multiple renaming may destroy even more equity than single renaming. However, rebranding enhances, regains, transfers and/or recreates brand equity (Muzellec\& Lambkin, 2006). Brand equity consists of the assets and liabilities of a brand (Aaker 1992). Customer loyalty accounts for a sizeable part of a brand's assets. In mobile telephony, customers may be retained on a network because of switching costs, but they may no longer be loyal to that network. Searching through literature, there is neither record of any such phenomenon as multiple rebranding, nor quest into its effect on customer loyalty. The purpose of this research, therefore, is to know customers' feelings and attitude (Rundle-Thiele 2001) towards the multiple rebranding of the network that was Econet Wireless; hence, the question: what is the effect of multiple rebranding on customer loyalty? The rest of the paper will be divided into five parts: a review of literature; theoretical basis of the research; the methodology employed; the presentation and analysis of data; discussion of results, recommendations and suggestions for further research. 


\section{Literature Review}

\subsection{The Meaning of Rebranding}

Rebranding is a relatively new research area. Different scholars have proffered their own understanding of the phenomenon, gradually building up a body of knowledge to crystallize the concept, definition and model of rebranding. Building on the American Marketing Association's (1985) definition of a brand, Muzellec and Lambkin (2006) posit that rebranding can be defined as the creation of a new name, term, symbol, design or a combination of them for an established brand with the intention of developing a differentiated (new) position in the minds of stakeholders and competitors. Also building on the definition of Einwiller and Will (2002) for corporate branding, Juntenen, Saraniemi \& Jussila(2009) consider corporate rebranding as a systematically planned and implemented process of creating and maintaining a new favourable image and consequently a favourable reputation of the company as a whole by sending signals to all stakeholders and by managing behaviour, communication and symbolism in order to pro-act or react to change. Breaking away from the mould of adapting existing definitions, Merrilees and Miller (2007) propose a theory of the rebranding process which entails brand re-visioning, internal branding and brand strategy implementation. Ahonen (2008b) presents a five-phased process consisting analysing, planning, implementation and evaluation. Building on this, Alahuhta (2009) increased the process to seven phases: triggering, analysing and decision-making, planning, preparing, launching, evaluating and continuing stages.

Table 1. Summary of works on rebranding. Culled from Goi and Goi (2011)

\begin{tabular}{|c|c|c|c|c|c|}
\hline REFERENCE & $\begin{array}{l}\text { Melewar, } \\
\text { Hussey \& } \\
\text { Srivoravilai } \\
\text { (2005) }\end{array}$ & $\begin{array}{l}\text { Moloney and } \\
\text { Daly (2004) }\end{array}$ & Causon (2004) & $\begin{array}{l}\text { Muzellec, } \\
\text { Doogan \& } \\
\text { Lambkin } \\
(2003)\end{array}$ & $\begin{array}{l}\text { Lomax, Mador } \\
\text { \& Fitzhenry } \\
\text { (2002) }\end{array}$ \\
\hline $\begin{array}{l}\text { PURPOSE OF } \\
\text { STUDY }\end{array}$ & $\begin{array}{l}\text { To explore } \\
\text { France } \\
\text { Telecom's visual } \\
\text { rebranding } \\
\text { programme }\end{array}$ & $\begin{array}{l}\text { Continues } \\
\text { exploration of } \\
\text { Muzellec et al } \\
\text { (2003) study and } \\
\text { presents a case } \\
\text { history of a } \\
\text { company }\end{array}$ & $\begin{array}{l}\text { The process of } \\
\text { managing the } \\
\text { change } \\
\text { programme } \\
\text { within the } \\
\text { organisation as it } \\
\text { rebrand and } \\
\text { reposition }\end{array}$ & $\begin{array}{l}\text { Investigated the } \\
\text { corporate } \\
\text { rebranding } \\
\text { phenomenon }\end{array}$ & $\begin{array}{l}\text { Qualitative } \\
\text { study } \\
\text { Examine seven } \\
\text { UK based } \\
\text { organisation } \\
\text { which have } \\
\text { rebranded in } \\
\text { the past five } \\
\text { years }\end{array}$ \\
\hline FINDINGS & $\begin{array}{l}\text { The process of } \\
\text { rebranding: } \\
\text { Problem } \\
\text { recognition, } \\
\text { development of } \\
\text { strategies, } \\
\text { execution of } \\
\text { plan, } \\
\text { implementation } \\
\text { and reviewing of } \\
\text { impact. }\end{array}$ & $\begin{array}{l}\text { Corporate } \\
\text { rebranding } \\
\text { framework: } \\
\text { Analysis - } \\
\text { market analysis, } \\
\text { brand audit, } \\
\text { opportunity } \\
\text { identification } \\
\text { Planning - } \\
\text { communicating } \\
\text { tointernal } \\
\text { customers, } \\
\text { renaming } \\
\text { strategy, the } \\
\text { rebranding } \\
\text { market plan and } \\
\text { Evaluation }\end{array}$ & $\begin{array}{l}\text { Three stages: the } \\
\text { education phase } \\
\text { The } \\
\text { identification } \\
\text { phase } \\
\text { The } \\
\text { implementation } \\
\text { phase }\end{array}$ & $\begin{array}{l}\text { Rebranding } \\
\text { mix: } \\
\text { Repositioning } \\
\text { Renaming } \\
\text { Redesigning } \\
\text { Relaunching }\end{array}$ & $\begin{array}{l}\text { Conceptual } \\
\text { model of the } \\
\text { rebranding } \\
\text { process: } \\
\text { Trigger new } \\
\text { brand } \\
\text { development } \\
\text { Project } \\
\text { management } \\
\text { Follow - } \\
\text { through }\end{array}$ \\
\hline
\end{tabular}

Note: Table 1 is a summary of the process of rebranding that other scholars proffer. 


\subsection{The Causes of Rebranding}

According to Muzellec and Lambkin (2006) rebranding is undertaken for the broad reasons of change in ownership, corporate strategy, external environment as well as competitive position. Each of these causes can be further broken down into other specific causes in different situations in different sectors of the economy.

\subsection{The Costs of Rebranding}

Rebranding leads to loss of identity (Jaju, Joiner, \& Reddy, 2006). Undertaking it is not only risky, it also has huge financial implications (Aaker 1996; Keller 2002; Stuart \& Muzellec, 2004). Therefore, there must be enough justification for undertaking it (Stuart \& Muzellec, 2004).

\subsection{The Goal of Rebranding}

Branding builds equity (Aaker, 1996). Rebranding enhances, regains, transfers and/or recreates brand equity (Muzellec\& Lambkin, 2006). Brand equity is defined as a set of brand assets and liabilities linked to a brand name and symbol (Aaker, 1992). Sometimes, the whole essence of a rebranding exercise may be to drop all or some of the liabilities of a brand (Muzellec \& Lambkin, 2006). This is one of the fundamental differences between branding and rebranding.

\subsection{The Extent of Rebranding}

Muzellec and Lambkin (2006) describe rebranding as being either evolutionary or revolutionary. Evolutionary rebranding occurs when there is a change in the marketing aesthetics of a brand, while revolutionary rebranding is typified by a name change. Between the two types of rebranding is a continuum (Stuart and Muzellec, 2004). Muzellec and Lambkin (2006) also proffer a concept of rebranding based on hierarchy. They observe three levels at which rebranding occurs, namely; corporate, business unit and product levels. An example of a business unit rebranding is where a mortgage institution or an insurance company under the umbrella name of a financial institution undergoes a name change, although it is still owned by the umbrella company. Lomax et al (2006) present an alternative approach to the possibilities in rebranding based on change of name and change of values and attributes. They suggest four perspectives to rebranding: (i) change in name due to change in ownership structure, without change in attributes and values (ii) change in attributes and values owing to a mismatch of name and attributes (iii) a new start that changes name and values (iv) no need to change name and attributes

\subsection{The Models of Rebranding}

In an attempt to capture the meaning of rebranding scholars are gradually shifting away from a compact definition to a description of the rebranding process in order to accommodate its entire ramification. This has given rise to the creation of a couple of rebranding models. However, searching through available literature, noteworthy is the absence of any work on multiple rebranding, though it has been for some years a present experience in the telephony industry in Nigeria, an emerging market.

\subsection{Research Question Arising from Gap in Literature}

Since there is no literature addressing the phenomenon of multiple rebranding, the question: 'What is the effect of multiple rebranding on customer loyalty?' becomes imperative, because customer loyalty is a critical factor in brand equity. And brand equity is the whole essence of branding, whether single or multiple rebranding.

\section{Theoretical Framework}

\subsection{Communication: The Mediator for Rebranding and Multiple Rebranding}

The more comprehensive definition of rebranding which states that rebranding is 'a systematically planned and implemented process of creating and maintaining a new favourable image and consequently a favourable reputation of the company as a whole by sending signals to all stakeholders and by managing behaviour, communication and symbolism in order to pro-act or react to change', suggests that 'sending signals to all stakeholders' and the 'behaviour' of the internal audience; the communication to which the external public is exposed; and the 'symbolism' in the communication and brand identity during rebranding are the key factors in creating brand equity. Incidentally, all these activities are communication processes in one form or another. The sending of signals to all stake holders is a communication process; the behaviour the internal public should put up towards customers is communicated to them; the desired behaviour of the internal public communicates brand values to the customer; the brand identity and symbolism are signs that have communicative significance. Communication is the exchange of meaning. All said, to rebrand is to communicate. If all of rebranding is communication, then there must be a communication theory that explains the process of rebranding. That theory is The Information Processing Theory (Anaeto, Onabajo, \& Osifeso, 2008). The theory explains how each message is filed and modified based on new message received on the same issue. Decision and action of the 
recipient of a message is based on the last version of the modified message.It takes seeing and agreeing with the communicated need for change, before both the internal and external public can change their attitude towards a rebranding process. Each stage of the rebranding process is a re-enactment of the theory.

\subsection{Multiple Rebranding}

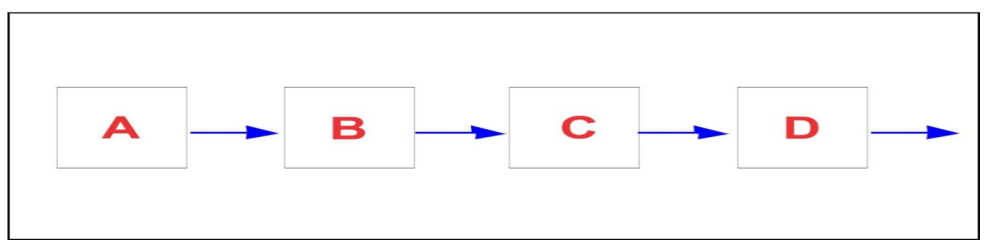

Figure 1. Model of multiple re-branding

This model is to show that multiple corporate rebranding happens when a business organization rebrands two or more times.

\subsection{The Relationship between Multiple Rebranding and Customer Loyalty}

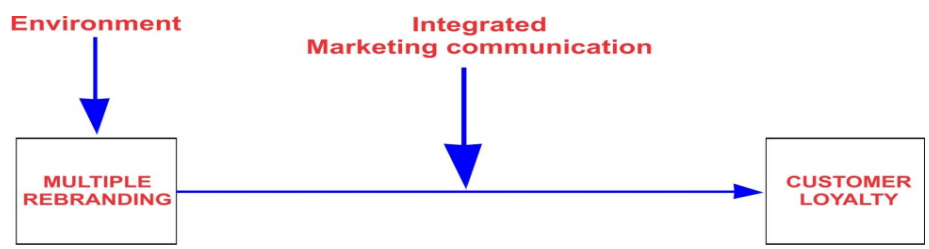

Figure 2. The multiple re-branding - customer loyalty model

The interaction between multiple rebranding (and indeed branding and single rebranding) and customer loyalty is mediated by communication. As in the Information Processing Theory, each new message received modifies the previous one filed away on the same subject matter. The receiver then makes a decision based on the latest modification. After which the receiver takes action. The action may be to agree or disagree with the modified impression. An agreement will mean a positive change in attitude towards the filed modification. Agreement is equal to loyalty. Disagreement is otherwise.

\subsection{Theoretical Framework of Hypotheses}

Based on the factors involved in the model for the relationship between customer loyalty and multiple rebranding, three hypotheses were developed for testing:

$\mathrm{H} 1$ : Communication transfers brand equity in multiple rebranding.

Customers file away information concerning a brand, and reshuffle it when new information about the brand is received. This way, a consumer assimilates the changes that occur around a brand and determine his disposition towards the brand. This disposition may be loyalty, disloyalty or indifference.

H2: Multiple rebranding does not affect customer loyalty.

Consumer loyalty is measured by behaviour or attitude. Behaviour is measured by repeat purchase and share of pocket; while attitude is measured by repurchase and recommendation based on intangible factors. Examples of intangible factors are feelings, beliefs, etc. The attitude of customers towards a brand is a very good measure of loyalty in the service industry (Rundle-Thiele 2001).

H3: Customers do not care about branding in the Nigerian mobile telephony.

A brand should stand for something in the minds of consumers. Their bond with the brand should go beyond its functional benefit to include an emotional attachment that makes them easily recall such brand properties as its logo, slogan, colours and other associations with the brand's positioning.

The tests for the hypotheses will be done empirically. 


\section{Methodology}

The question to be researched through the methodology is: 'What is the effect of multiple rebranding on customer loyalty?'

\subsection{Survey Design}

To know the feelings and attitude (Rundle-Thiele 2001) of subscribers towards Airtel as a result of the multiple rebranding through which it emerged, correlation survey design was adopted for this study. Cluster sampling technique was used to administer questionnaires.

\subsection{Characteristics of Study Population}

The population of the study is all gsm subscribers in general and those of Airtel in particular. However, sampling was carried out only in Lagos. Lagos State has the highest number of gsm subscribers and a good representation of gsm users. The sampling was carried out mostly amongst the full-time and part-time students of Yaba College of Technology, Yaba, Lagos.

\subsection{Sample Size and Sampling Procedure}

$2 \mathrm{OO}$ questionnaires were printed for Airtel customers; and 100 questionnaires for the customers of each of the other gsm operators, 500 questionnaires in all. Nevertheless, in the process of administering the questionnaires some were damaged and others were either not filled at all or not completely. These account for the shortfall in the numbers recorded.

\subsection{Type of Data and Data Collection}

Primary data was collected through the instrumentality of a questionnaire. Some questions were closed-ended; using the Likert scale or requiring simple 'Yes' or 'No'. Others were open-ended. The open-ended ones were meant to allow the respondents express themselves freely. The data collected from Airtel customers was somewhat different from the one for the rest of the customers of the gsm companies, which was the same in every way, except company name. The data requested from the customers of other GSM companies apart from Airtel was essential to find out if they left Airtel for their present network, and whether or not they were loyal to their present network and the reason behind it. The data for both sets were divided into two halves: one, for psychographic questions and two, for demographic questions.

\section{Presentation and Interpretation of Data}

\subsection{Presentation of Data}

Table 2. How did you get to know about each name change? Were you aware of each name change on your network?

\begin{tabular}{|c|c|c|c|c|c|}
\hline & & & \multicolumn{2}{|c|}{$\begin{array}{l}\text { Were you aware o } \\
\text { each name change or } \\
\text { your network? }\end{array}$} & \multirow{2}{*}{ Total } \\
\hline & & & YES & NO & \\
\hline \multirow{4}{*}{$\begin{array}{l}\text { How did you get to know } \\
\text { about each name change? }\end{array}$} & MEDIA & Count & 107 & 8 & 115 \\
\hline & & $\%$ of Total & $78.1 \%$ & $5.8 \%$ & $83.9 \%$ \\
\hline & WORD OF MOUTH & Count & 18 & 4 & 22 \\
\hline & & $\%$ of Total & $13.1 \%$ & $2.9 \%$ & $16.1 \%$ \\
\hline \multirow[t]{2}{*}{ Total } & & Count & 125 & 12 & 137 \\
\hline & & $\%$ of Total & $91.2 \%$ & $8.8 \%$ & $100.0 \%$ \\
\hline
\end{tabular}

\begin{tabular}{lllll}
\hline Chi-Square Tests & & & & \\
\hline & Value & df & $\begin{array}{l}\text { Asymp. } \\
(2-\text { sided })\end{array}$ & Sig. \\
\hline Pearson Chi-Square & $2.912^{\mathrm{a}}$ & 1 & .088 & \\
\hline
\end{tabular}


Table 3. What was your first reaction to each name change? How long have you been using your airtel line? Crosstabulation

\begin{tabular}{|c|c|c|c|c|c|c|c|}
\hline & & & \multicolumn{4}{|c|}{ How long have you been using your airtel line? } & \multirow[b]{2}{*}{ Total } \\
\hline & & & Under 1 year & $1-2$ years & $3-5$ years & $\begin{array}{l}\text { more than } \\
5 \text { years }\end{array}$ & \\
\hline \multirow{10}{*}{$\begin{array}{l}\text { What was your first } \\
\text { reaction to each name } \\
\text { change? }\end{array}$} & Very happy & Count & 1 & 1 & 2 & 1 & 5 \\
\hline & & $\%$ of Total & $.7 \%$ & $.7 \%$ & $1.4 \%$ & $.7 \%$ & $3.6 \%$ \\
\hline & Happy & Count & 0 & 1 & 6 & 2 & 9 \\
\hline & & $\%$ of Total & $.0 \%$ & $.7 \%$ & $4.3 \%$ & $1.4 \%$ & $6.4 \%$ \\
\hline & Indifferent & Count & 12 & 12 & 23 & 30 & 77 \\
\hline & & $\%$ of Total & $8.6 \%$ & $8.6 \%$ & $16.4 \%$ & $21.4 \%$ & $55.0 \%$ \\
\hline & Unhappy & Count & 6 & 11 & 14 & 9 & 40 \\
\hline & & $\%$ of Total & $4.3 \%$ & $7.9 \%$ & $10.0 \%$ & $6.4 \%$ & $28.6 \%$ \\
\hline & Very unhappy & Count & 0 & 1 & 5 & 3 & 9 \\
\hline & & $\%$ of Total & $.0 \%$ & $.7 \%$ & $3.6 \%$ & $2.1 \%$ & $6.4 \%$ \\
\hline \multirow{2}{*}{\multicolumn{2}{|c|}{ Total }} & Count & 19 & 26 & 50 & 45 & 140 \\
\hline & & $\%$ of Total & $13.6 \%$ & $18.6 \%$ & $35.7 \%$ & $32.1 \%$ & $100.0 \%$ \\
\hline
\end{tabular}

\begin{tabular}{lllll}
\hline Chi-Square Tests & & & & \\
\hline & Value & df & $\begin{array}{l}\text { Asymp. } \\
(2 \text {-sided) }\end{array}$ & Sig. \\
\hline Pearson Chi-Square & $12.471^{\mathrm{a}}$ & 12 & .409 & \\
\hline
\end{tabular}

Table 4. How do you feel about the name change now? How long have you been using your Airtel line? Crosstabulation

\begin{tabular}{|c|c|c|c|c|c|c|c|}
\hline & & & \multicolumn{4}{|c|}{ How long have you been using your Airtel line? } & \multirow[b]{2}{*}{ Total } \\
\hline & & & Under 1 year & $1-2$ years & $3-5$ years & $\begin{array}{l}\text { more than } \\
5 \text { years }\end{array}$ & \\
\hline \multirow{10}{*}{$\begin{array}{l}\text { How do you feel about } \\
\text { the name change now? }\end{array}$} & Very happy & Count & 2 & 1 & 3 & 4 & 10 \\
\hline & & $\%$ of Total & $1.4 \%$ & $.7 \%$ & $2.1 \%$ & $2.8 \%$ & $7.1 \%$ \\
\hline & Happy & Count & 2 & 6 & 10 & 10 & 28 \\
\hline & & $\%$ of Total & $1.4 \%$ & $4.3 \%$ & $7.1 \%$ & $7.1 \%$ & $19.9 \%$ \\
\hline & Indifferent & Count & 12 & 14 & 24 & 25 & 75 \\
\hline & & $\%$ of Total & $8.5 \%$ & $9.9 \%$ & $17.0 \%$ & $17.7 \%$ & $53.2 \%$ \\
\hline & Unhappy & Count & 2 & 4 & 10 & 4 & 20 \\
\hline & & $\%$ of Total & $1.4 \%$ & $2.8 \%$ & $7.1 \%$ & $2.8 \%$ & $14.2 \%$ \\
\hline & Very unhappy & Count & 1 & 2 & 3 & 2 & 8 \\
\hline & & $\%$ of Total & $.7 \%$ & $1.4 \%$ & $2.1 \%$ & $1.4 \%$ & $5.7 \%$ \\
\hline \multirow{2}{*}{\multicolumn{2}{|c|}{ Total }} & Count & 19 & 27 & 50 & 45 & 141 \\
\hline & & $\%$ of Total & $13.5 \%$ & $19.1 \%$ & $35.5 \%$ & $31.9 \%$ & $100.0 \%$ \\
\hline
\end{tabular}

\begin{tabular}{lllll}
\hline Chi-Square Tests & & & & \\
\hline & Value & df & $\begin{array}{l}\text { Asymp. } \\
(2 \text {-sided) }\end{array}$ & Sig. \\
\hline Pearson Chi-Square & $5.289^{\mathrm{a}}$ & 12 & .948 \\
Likelihood Ratio & 5.501 & 12 & .939 \\
Linear-by-Linear & .481 & 1 & .488 \\
Association & 141 & & & \\
N of Valid Cases & & &
\end{tabular}

Note: a. 11 cells $(55.0 \%)$ have expcount is 1.08 . 
Table 5. How do you feel of Airtel's customer relations? How long have you been using your Airtel line? Crosstabulation

\begin{tabular}{|c|c|c|c|c|c|c|c|}
\hline & & & \multicolumn{4}{|c|}{ How long have you been using your Airtel line? } & \multirow[b]{2}{*}{ Total } \\
\hline & & & Under 1 year & $1-2$ years & $3-5$ years & $\begin{array}{l}\text { more than } \\
5 \text { years }\end{array}$ & \\
\hline \multirow{10}{*}{$\begin{array}{l}\text { How do you feel about } \\
\text { Airtel's customer } \\
\text { relations? }\end{array}$} & Very happy & Count & 4 & 5 & 10 & 9 & 28 \\
\hline & & $\%$ of Total & $3.1 \%$ & $3.9 \%$ & $7.8 \%$ & $7.0 \%$ & $21.9 \%$ \\
\hline & Happy & Count & 5 & 10 & 18 & 18 & 51 \\
\hline & & $\%$ of Total & $3.9 \%$ & $7.8 \%$ & $14.1 \%$ & $14.1 \%$ & $39.8 \%$ \\
\hline & Indifferent & Count & 5 & 3 & 9 & 10 & 27 \\
\hline & & $\%$ of Total & $3.9 \%$ & $2.3 \%$ & $7.0 \%$ & $7.8 \%$ & $21.1 \%$ \\
\hline & Unhappy & Count & 2 & 6 & 4 & 4 & 16 \\
\hline & & $\%$ of Total & $1.6 \%$ & $4.7 \%$ & $3.1 \%$ & $3.1 \%$ & $12.5 \%$ \\
\hline & Very unhappy & Count & 2 & 1 & 2 & 1 & 6 \\
\hline & & $\%$ of Total & $1.6 \%$ & $.8 \%$ & $1.6 \%$ & $.8 \%$ & $4.7 \%$ \\
\hline \multirow[t]{2}{*}{ Total } & & Count & 18 & 25 & 43 & 42 & 128 \\
\hline & & $\%$ of Total & $14.1 \%$ & $19.5 \%$ & $33.6 \%$ & $32.8 \%$ & $100.0 \%$ \\
\hline
\end{tabular}

\begin{tabular}{lllll}
\hline Chi-Square Tests & & & & \\
\hline & Value & df & $\begin{array}{l}\text { Asymp. } \\
(2 \text {-sided) }\end{array}$ & Sig. \\
\hline Pearson Chi-Square & $7.797^{\mathrm{a}}$ & 12 & .801 & \\
\hline
\end{tabular}

Table 6. How do you feel about the name change now? If it were possible to move to another network with your Airtel line, would you have done that? Crosstabulation

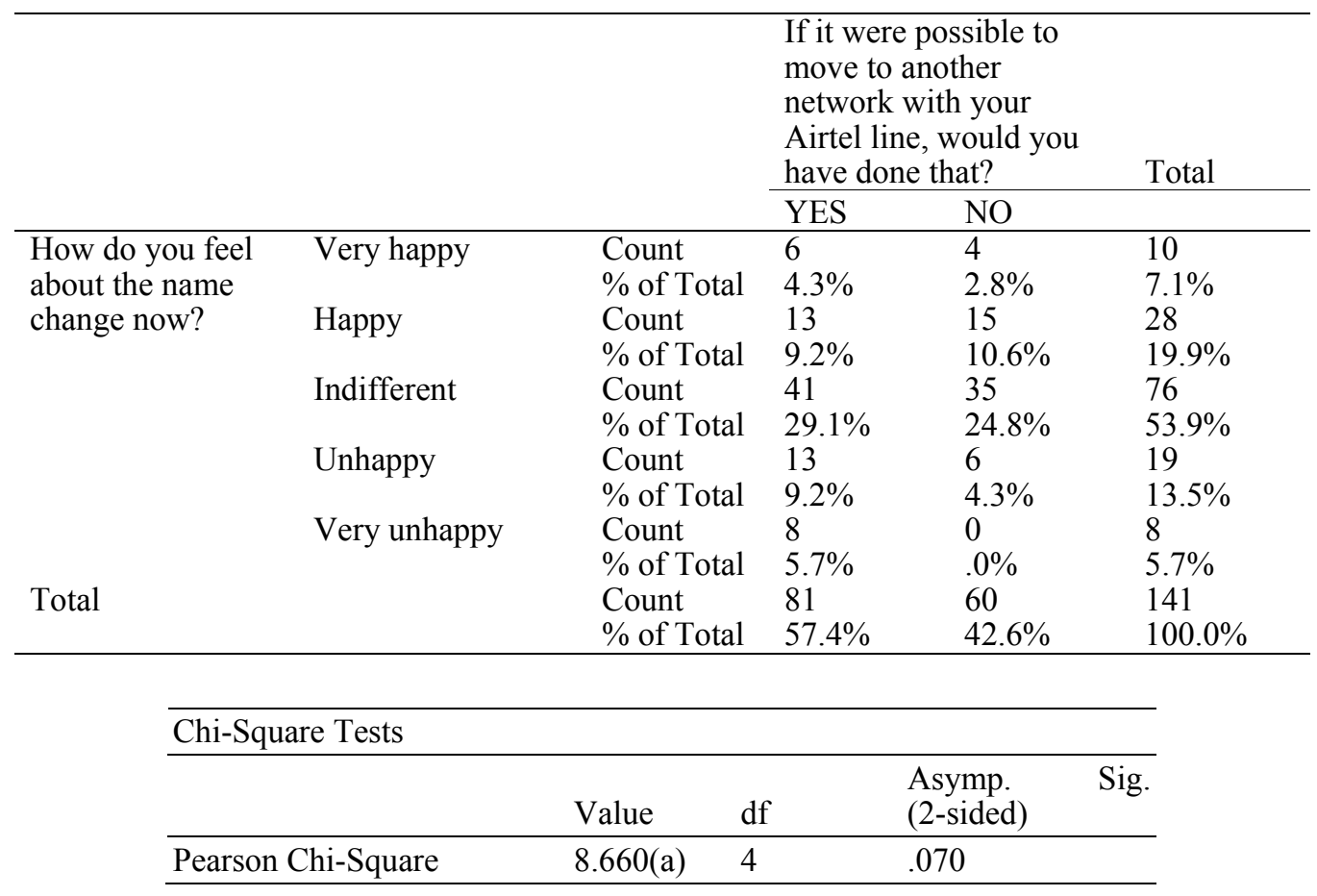


Table 7. How do you feel about the name change now? Would you recommend Airtel to someone getting a gsm line for the first time? Crosstabulation

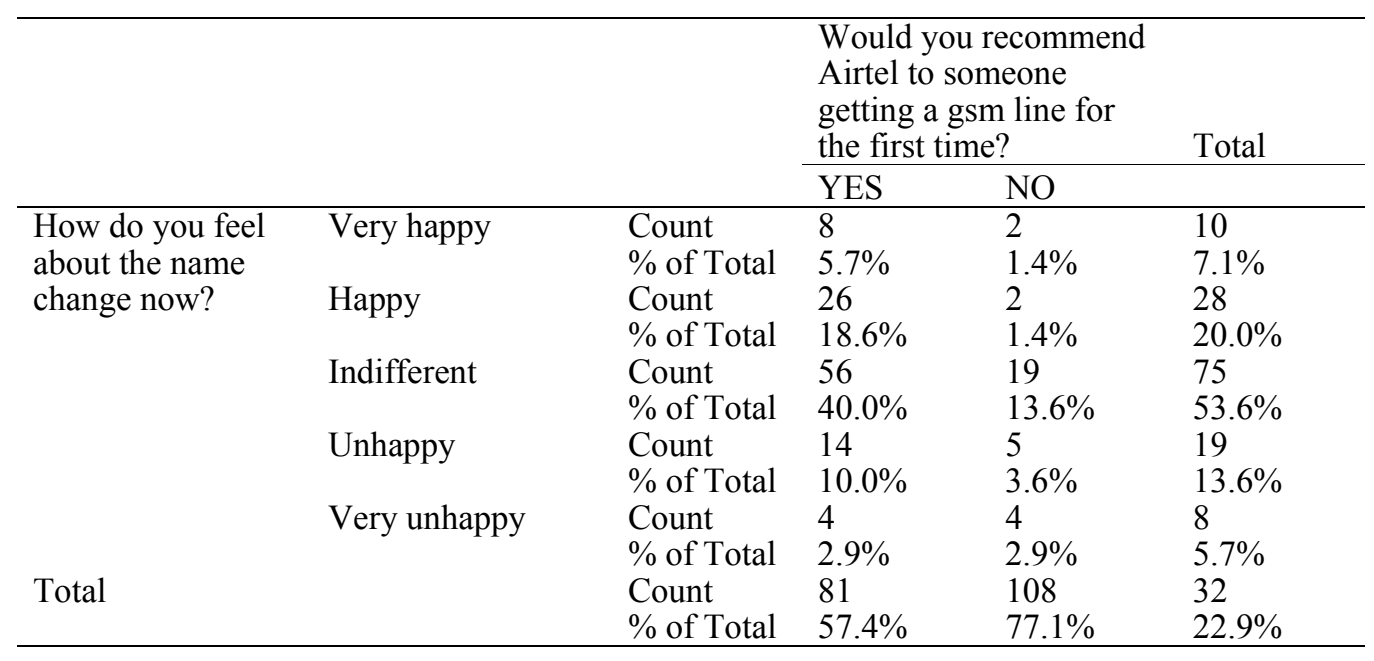

\begin{tabular}{lllll}
\hline Chi-Square Tests & & & & \\
\hline & Value & df & $\begin{array}{l}\text { Asymp. } \\
\text { (2-sided) }\end{array}$ & Sig. \\
\hline Pearson Chi-Square & $7.700(a)$ & 4 & .103 & \\
\hline
\end{tabular}

\subsection{Analysis of the Research Question}

The question to be answered through the results of the data analysed was: 'What is the effect of multiple rebranding on customer loyalty?'

The results will now be used to confirm or refute the hypotheses arising from the research question.

\subsubsection{Test of Hypotheses}

H1: Communication transfers brand equity in multiple rebranding.

From the result of the cross tabulation, most GSM subscribers were well aware of the rebranding exercises (91.2\%). It is also clear that most subscribers got to know through the media (78.1\%); based on Integrated Marketing Communications employed during each exercise or the word of mouth it generated (13.1\%). The equity of a brand revolves around its brand name. Ultimately, all the desirable associations are eventually built around the brand name. Nevertheless, it must be said that multiple rebranding also causes some brand confusion. Subscribers continue to call a brand its previous names for quite some time $(90.7 \%$ of Airtel subscribers and $86.1 \%$ of other gsm network subscribers).

$\mathrm{H} 2$ : Multiple rebranding does not affect customer loyalty.

Results show that more than half the subscribers, no matter how long they have been on the network, were indifferent to the first single rebranding $(55.0 \%)$ and to all the multiple rebranding $(53.9 \%)$. Results also show that $42.6 \%$ subscribers were loyal to the network (will not move from the network even if they have the opportunity) after the multiple rebranding. Only $19.5 \%$ have negative feelings towards the network, and of these, $4.3 \%$ remain loyal to the network $77.1 \%$ of the subscribers will recommend the network. Only $19.3 \%$ have negative feelings towards the network, and of these, $12.9 \%$ remain loyal to the network. Therefore, the results suggest indifference to multiple rebranding. It confirms the hypothesis.

H3: Customers do not care about branding in the Nigerian mobile telephony.

From the results, about half the respondents for all networks do not care about the name of the network that provides them gsm telephony (MTN 51.4\%, GLO 40.0\%, ETISALAT 41.3\% and AIRTEL 55.1\%); and close to half do not associate their networks to anything as judged by the lack of information on that question; and, for those who do, there was little or no association with brand slogan, icons, symbols, colours, or any such brand property. The impression here is either that Nigerians do not really care about branding in mobile telephony or the telecommunications companies have not done a good job of positioning their brands in the minds of subscribers. It confirms the hypothesis. 


\section{Discussions and Conclusion}

\subsection{Summary of Findings}

This research confirms communication as the vehicle for transferring brand equity; shows that multiple rebranding does not significantly affect attitude towards telecommunications brands; and that Nigerians do not really care about branding in telecommunications and/or the telecommunications companies are not doing a good job of branding.

\subsection{Discussions}

The findings on each hypothesis will now be looked at more closely in the light of factors internal to the research, and the result of similar works done around the world.

\section{H1: Communication transfers brand equity in multiple rebranding.}

The work of Daly and Moloney (2004) confirm the ability of integrated marketing communication to register a new brand name in the minds of customers. Customers who recognise the brand by its new name and continue to do business with it are part of transferred brand equity. The equity of a brand revolves around its name. Ultimately, all the desirable associations are eventually built around the brand name through communication and corporate staff behaviour. Nevertheless, it must be said that multiple rebranding also causes some brand confusion. Subscribers continue to call a brand its previous names for quite some time before the new name finally takes over (90.7\% among Airtel subscribers and $86.1 \%$ among others)

$\mathrm{H} 2$ : Multiple rebranding does not affect customer loyalty.

The model Muzellec and Lambkin (2006) created for rebranding shows the need for good customer relations on the part the staff of any organization undergoing corporate rebranding. The works of Roberts-Lombard (2011) and Sathish, Naveen \& Jeevanantham(2011) have pointed out customer relations as a key factor in customer loyalty or the acceptance of a new brand. Given that most subscribers of the network under study have other lines $(78.6 \%)$, it is clear that the network under study must have had good customer relations all through its different phases and faces $(51.9 \%$ had positive feelings towards the network's customer relations before it became Airtel and $61.7 \%$ after). This could have made up for the negative feelings multiple rebranding might have generated. Oyeniyi and Abiodun (2008) found customer service to be strongly related to customer retention in the Nigerian mobile telephony.

H3: Customers do not care about branding in the Nigerian mobile telephony.

From the results, Nigerians were more concerned with functional issues like brand awareness, reliability of network, service price, keeping of contacts, etc., which have been suggested as good antecedents for customer loyalty in emerging markets (Kim \& Lee, 2010). Although each of the networks has had consistent logo, slogan, colours, etc., over the years, these were not associated with the brands un-prompted. They do not seem to be as important to Nigerians as the ability to communicate. It would seem that Nigerians just want to communicate, not minding who provides the services. The use of gsm lines as the only available means of telephony for the majority of the people can also be an explanation for this.

\subsection{Conclusion}

Based on the results of this research, it is clear that in Nigeria, an emerging market where gsm lines are the only source of telephony to the majority of the people, subscribers are aware of such phenomenon as multiple rebranding, but are indifferent to it, in so far as the network gives them the needed telecommunication services and has good customer relations. Furthermore, un-prompted, none of the gsm networks actually stands for anything distinct in the minds of the subscribers, except the names of the networks.

\subsection{Recommendations}

From this study, the following recommendations can be made:

(I) It is better not to rebrand very often in the telephony business, but if that must happen, the functional benefits of such a network should remain very good or even better. Plus, excellence should be maintained in customer service on the part of company staff. All these will help keep subscribers loyal in spite of multiple rebranding

(II) Telecommunications companies should spend less on product advertisement, and divert more money into building quality networks with low call tariff. The present practice of promotional activities and the creation of products that require huge advertising spend should be either scrapped or curtailed. And the efforts in brand building should be geared towards making the network stand for something in the minds of subscribers. 


\subsection{Suggestion for Further Studies}

Perhaps, more than anything else is the need to study multiple rebranding whilst it is taking place. A repeated study of rebranding within an organization while the rebranding is taking place will give a truer picture of the phenomenon. This study is limited to a segment of gsm subscribers. It will make a good research subject to study all the segments of subscribers simultaneously. Also, it will be good to know the effect of multiple rebranding on the image of a brand in the short and long run. A study of multiple rebranding in other sectors will help to better understand the phenomenon.

\section{References}

Aaker, D. (1996). Resisting the temptation to change a brand position/execution: the power of consistency over time. Journal of Brand Management, 3(4), 8.

Aaker, D. A. (1992). Managing the most important asset: Brand equity. Planning Review, 20(5), 56-58. http://dx.doi.org/10.1108/eb054384

Ahonen, M. (2008b). Corporate rebranding process: A Preliminary Theoretical Framework. Proceedings of the conference on Corporate Communications, June 6th - 9th, Wroxton, England; 41-48.

Alahuhta, J. (2009). Transferring brand equity hierarchically through rebranding. A Master's Thesis, Department of Marketing, University of Oulu, Finland.

American Marketing Association (AMA). (1985). Board approves new marketing definition. Marketing News, p.1.

Anaeto, S. G., Onabajo, O. S., \& Osifeso, J. B. (2008). Models and Theories of Communication. African Renaissance Books Incorporated, Maryland, USA.

Causon, J. (2004). The Internal Brand: Successful Cultural Change and Employee Empowerment. Journal of Change Management, 4(4), 297-307. http://dx.doi.org/10.1080/1469701042000259631

Daly, A., \& Moloney, D. (2004). Managing Corporate Rebranding. Irish Marketing Review, 17(1/2), 30-36.

Einwiller, S., \& Will, M. (2002). Towards an integrated approach to corporate branding - an empirical study. Corporate Communications, 7(2), 100. http://dx.doi.org/10.1108/13563280210426160

Goi, C., \& Goi, M. (2011). Review on models and reasons of rebranding. International conference on social and humanity, 5. Singapore: IACSIT Press.

Jaju, A., Joiner, C., \& Reddy, S. R. (2006). Consumer evaluation of corporate brand redeployments. Journal of Academy of Marketing Science, 34(2), 206-15. http://dx.doi.org/10.1177/0092070305284989

Juntenen, S., \& Jussila, R. (2009). Corporate rebranding as a process. Proceedings of the 5th Thought Leaders Conference on Brand Management, 6th-7th April 2009, Athens, Greece.

Keller, K. L. (2002). Branding and Brand Equity. Marketing Science Institute, Cambridge, MA.

Kim, Y., \& Lee, J. (2010). Relationship between corporate image and customer loyalty in mobile communication service markets. African Journal of Business Management, 4(18), 4035-4041.

Lomax, W., Mador, M., \& Fitzhenry, A. (2002). Corporate rebranding: learning from experience. Ocassional Paper Series, No 48. Retrieved from http://business.Kingston.ac.uk/papers/opres 48.pdf

Melewar, T. C., Hussey, G., \& Srivoravilai, N. (2005). Corporate Visual Identity: The Re-Branding of France Telecom. Journal of Brand Management, 12(5), 379-394. http://dx.doi.org/10.1057/palgrave.bm.2540233

Merrilees, B., \& Miller, D. (2008). Principles of corporate rebranding. European Journal of Marketing, 42(5/6), 537-552. http://dx.doi.org/10.1108/03090560810862499

Muzellec, L., \& Lambkin, M. (2006). Corporate rebranding: destroying, transferring or creating brand equity? European Journal of Marketing, 40(7/8), 803-824. http://dx.doi.org/10.1108/03090560610670007

Muzellec, L., Doogan, M., \& Lambkin, M. (2003). Corporate rebranding: an exploratory review. Irish Marketing Review, 16(2), 31.

Oyeniyi, O., \& Abiodun, A. J. (2008). Customer service in the retention of mobile phone users in Nigeria. African Journal of Business Management, 2(2).

Roberts-Lombard, M. (2011). Customer retention through customer relationship management: The exploration of two-way communication and conflict-handling. African Journal of Business Management, 5(9), 3487-3496. 
Rundle-Thiele, S., \& Benett, R. (2001). A brand for all seasons: A discussion of brand loyalty approaches and their applicability for different markets. Journal of product and brand management, 6(1), 40-48.

Sathish, M., Naveen, K. J., \& Jeevanantham, V. (2011). A Study on Consumer Switching Behavior in Cellular Service provider. Far East Journal of Psychology and Business, 5(2), 13-22.

Stuart, H., \& Muzellec, L. (2004). Corporate make-overs: can a hyena be rebranded. Journal of Brand Management, 11, 472-482. http://dx.doi.org/10.1057/palgrave.bm.2540193 